\title{
The (In)Appropriateness of the WAR Metaphor in Response to SARS-CoV-2: A Rapid Analysis of Donald J. Trump's Rhetoric
}

\author{
Benjamin R. Bates* \\ School of Communication Studies, Ohio University, Athens, $\mathrm{OH}$, United States
}

The virus SARS-CoV-2 and the disease it causes (COVID-19) are unfamiliar topics to most publics. One mechanism used by political leaders to make the strange and unfamiliar more understandable and familiar to their publics is using metaphor. In his responses to SARS-CoV-2, US President Donald Trump used the WAR metaphor to shape public understanding. In this analysis, I reveal how the entailments chosen by Trump to complete this metaphor lead to rhetorical incoherence and undermine policy response to SARS-CoV02. I conclude with a call to reject WAR as a metaphor for understanding SARS-CoV-2 and COVID-19 and, instead, encourage adopting alternative metaphors to shape public understanding.

OPEN ACCESS

Edited by:

Mohan Jyoti Dutta,

Massey University, New Zealand

Reviewed by:

James Olumide Olufowote

University of Oklahoma, United States Elena Bruni,

Vienna University of Economics and Business, Austria

*Correspondence: Benjamin R. Bates batesb@ohio.edu

Specialty section:

This article was submitted to Health Communication,

a section of the journal Frontiers in Communication

Received: 27 March 2020

Accepted: 18 June 2020

Published: 30 June 2020

Citation:

Bates BR (2020) The

(In)Appropriateness of the WAR

Metaphor in Response to

SARS-CoV-2: A Rapid Analysis of

Donald J. Trump's Rhetoric.

Front. Commun. 5:50.

doi: 10.3389/fcomm.2020.00050
Keywords: SARS-CoV-2 (virus), COVID-19 (condition), rhetoric, public response, metaphor, Donald Trump

\section{INTRODUCTION}

When SARS-CoV-2, the novel coronavirus, began to spread, this virus also became a novel threat to health and well-being. Although there were initial attempts to downplay the severity of this virus, the COVID-19 pandemic caused by infection with SARS-CoV-2 also became a poorly understood threat to people worldwide. Although microbiologists, epidemiologists, and public health officials are still attempting to understand the biology, spread, and best response to SARS-CoV-2, broader publics are seeking to understand what SARS-CoV-2 and COVID-19 mean to them.

In his foundational work on how publics are encouraged to adopt action or accept policymaking in unfamiliar environments, Edelman (1971) argued that "people who are anxious and confused are eager to be supplied with an organized political order-including simple explanations of the threats they fear-and with reassurance that the threats are being countered" (p. 65). The threat of SARS-CoV-2 is precisely the kind of situation in which people want a clear and simple explanation of the threat is how to respond to it.

In the United States, President Donald Trump supplied a simple explanation of SARS-CoV2 and how he would respond. He positioned himself as a wartime president and declared a war on SARS-CoV-2. This new positioning was widely reported as the new way for the US public to understand this virus. The BBC reported that Trump "considered the country to be on a war footing in terms of fighting the virus” (Coronavirus, 2020, n.p.). Steve Bannon, Trump's former chief strategist, asserted to the Guardian, "We are at war, and now by necessity he is a 'wartime' president. Churchill rose to the occasion and secured his place in history. Trump's moment is here, to grasp or to lose" (Smith, 2020, n.p.). Time reported, "President Lyndon Johnson declared a war on poverty. President Richard Nixon declared a war on drugs. Now President Donald Trump has gone to war with a virus" (Bennett and Berenson, 2020, n.p.). Many other examples of public adoption of the war metaphor could be provided. 
Although Trump called himself a wartime president, it is important to remember that this is not actually a war. Trump's war is a metaphorical one. The use of $\mathrm{WAR}^{1}$ is what Lakoff and Johnson (1980) call a "structural metaphor," a metaphor in which a highly complicated and unfamiliar concept (in this case SARS-CoV-2) becomes conceptualized in terms of a more familiar concept (in this case war) to allow auditors to more readily understand the unfamiliar concept. In discussing illness, Hillmer (2007) notes that, "since an illness includes innumerable chemical processes inside the body which cannot directly be seen, we use the source domain of war to make those processes easier to understand" (p. 23). These processes, as identified by Lakoff et al. (1991), can include the naming of an ENEMY, a BATTLEGROUND, ATTACKS, WEAPONS, DEFENSES, VICTORY, and DEFEAT, among other subcategories. These processes, what Lakoff and colleagues call "entailments," are the further activation of associations with the familiar concept so as to allow the unfamiliar concept to be understood by the auditor. That is when a rhetor selects a vehicle for a metaphor, or chooses what is sometimes called a source domain, and further when they select some entailments and not others, thus drawing potential cognitive targets from the selected metaphor's source domain, the rhetor is attempting to activate a cluster of associations so that the auditor comes to understand the unfamiliar phenomenon in a way preferred by the rhetor. Because Trump used the metaphor of WAR and attempted to frame himself as a WARTIME president, it is important to unpack this metaphor and the way Trump used it in response to SARS-CoV-2.

To engage in this unpacking, I begin by outlining the role that metaphors play in shaping thought and action and, more specifically, the role that the WAR metaphor has played in US political rhetoric. I then turn to an analysis of Trump's tweets and press conferences to outline the entailments of this metaphor, specifically the creation of the ENEMY, SOLDIERS, HOMEFRONT actions, and VICTORY. In this analysis, I note the conceptual and policy coherencies and incoherencies that this metaphor enacts in Trump's statements. Finally, I conclude with a call to reject Trump's WAR metaphors as a means of public understanding of SARS-CoV-2 and outline briefly alternative possibilities for metaphorical action to enhance public understanding.

\section{METAPHORS IN RHETORIC}

As early as Aristotle's writing (Rhet. 1404b-1505b), metaphors have been viewed as a way of making the unfamiliar familiar by comparing an unknown thing to a known thing. The Greek roots of the term, a combination of "meta," carrying over, and "phoros," light, are themselves metaphorical in that the imply that the speaker can illuminate for the auditor an unfamiliar concept by bringing light over from a topic the auditor understand well to one they do not understand well. Although metaphors are

\footnotetext{
${ }^{1}$ Following the recommendations of Ivie $(1980,1984,1987)$, all terms associated with the WAR metaphor are placed in full capital letters to draw attention to their metaphorical, rather than actual, qualities.
}

sometimes addressed as mere figures of speech, for example in literary criticism, metaphors also operate to shape cognition and action.

At a cognitive level, the comparison in a metaphor allows the image of a familiar topic to replace the image of the unfamiliar thing in the auditor's mind (Lakoff and Johnson, 1980). Lakoff (1993) argues that "the locus of metaphor is not in language at all, but in the way we conceptualize one mental domain in terms of another" (p. 202). Although the reality described does not itself change, as different metaphors are used to describe reality the way the auditor understands his or her relationship to that reality changes. The cognitive operations of the metaphor go beyond comparison; a metaphor becomes a structural site of rhetorical invention in which the speaker and auditor are encouraged to elaborate on the metaphor in particular ways. Together, the speaker and the auditor engage in a process in which, as Ivie (1987) puts it, "elaborating a primary image into a well formed argument produces a motive, or interpretation of reality" (p. 166). This process of elaboration in a structural metaphor, like the WAR metaphor, encourages the speaker to select some entailments that are consistent with the metaphor and to deselect entailments that challenge the metaphor. Simultaneously, the auditor may, as in an enthymeme, fill in unmentioned entailments as she or he seeks to complete the metaphor and ignore entailments that disrupt the metaphor. The very structure of cognition may cause speaker and auditor, both, to "view the entailments of the metaphors as being true" even when they are, in fact, false or inconsistent with other aspects of reality (Lakoff and Johnson, 1980, p. 157).

In addition to reshaping thought, structural metaphors are reshape action. Metaphors, as Lakoff (2004) argues, are strong frames that guide more than language; rather, "they shape the goals we seek, the plans we make, the way we act, and what counts as a good or bad outcome of our actions" (p. xv). That is, when a metaphor becomes the structure for how we think about a topic, they make some goals, plans, actions, and outcomes thinkable and others unthinkable. Having embraced a metaphor, auditors operate as if that metaphor were an accurate description of reality and seek to enact the concrete policy goals, plans, and actions that are entailed by that metaphor (Ivie, 1984; Bates, 2004). As Ivie (1987) puts it, "the form of the argument actualizes and literalizes the potential of the incipient figure" (p. 166). The constant deployment of the metaphor, make perceptually required goals, policies, and actions that emerge as further ways to actuate and activate the structure of reality engendered by the metaphor. One place where this emergence has regularly occurred is in war rhetoric.

\section{WAR METAPHORS IN RHETORIC}

Within war rhetoric, there is a longstanding tradition of using metaphors to change understandings of public events and the appropriate responses to them. Most analyses have begun by indicating how the metaphors of ANIMAL (e.g., Knightly, 1975; Keen, 1991; Steuter and Wills, 2008) or SAVAGERY (e.g., Ivie, 1980, 1984, 1987; Zhang and Bates, 2017) are used to dehumanize 
the enemy and enable military action. For example, Mral (2006) shows that George W. Bush's extended use of a HUNTING metaphor after the events of September 11, 2001 removed human status from potential combatants and transformed killing them into an acceptable act. Alternatively, Bates (2004) shows that George H. W. Bush used metaphor to frame Iraq as SAVAGES and the US and its allies as CIVILIZED to justify waging the first Persian Gulf War, similarly removing human status from Iraqis but also compelling US-Americans and international publics to support battle with little, if any, questioning.

When the metaphor of WAR is transferred to help auditors understand other contexts, in their making the familiar unfamiliar the entailments of these metaphors can lead to affirming other understandings of associated persons, events, or phenomena, whether these affirmations are intentional or unintentional. For example, Mirghani (2011) examined anticopyright infringement campaigns' declaration of a WAR on PIRACY. She concludes that, by transforming computer users into PIRATES, the term's "historical baggage and its power as a provocative latent discourse" allows copyright enforcers to place PIRATES outside the law and its protections, and to authorize themselves "as a disciplining and policing force by evoking military metaphors" (p. 115). Similarly, Butterworth (2008) argues that, in the context of the steroids scandal in baseball, George W. Bush's "rhetoric surrounding steroids was articulated with the "war on terror"' (p. 153). This association not only allowed auditors to understand a WAR on steroids to be similar to the war in Afghanistan and Iraq, but also carried "the potential to constitute a pure, uncontaminated national community" that had been attacked (p. 153). As Butterworth demonstrates, this "pure" community that came to frame US-Americans led to racist scapegoating of immigrant baseball players and transforming the often-corrupt world of professional sports into an exemplar of the purity of the United States.

Although WAR can encourage the public to support political action, the understandings that the WAR metaphor creates can also stand in tension with political and policy possibilities. The WAR on drugs, at least as waged under Ronald Reagan, George H. W. Bush and Bill Clinton, Mackey-Kallis and Hahn (1994) argued, "circumscribed drug policy debate while creating a frustrated and sometimes apathetic American citizenry" (p. 2). This circumscription occurred because higher levels of militarized policies and the articulation of drug dealers and drug users as the enemy made vigilante and institutional violence acceptable and made drug education, drug rehabilitation, and drug legalization policy options incoherent with the metaphor and, thus, unthinkable as valid options.

This foreclosure of other options in strengthened by the way that WAR allows political actors to name an ENEMY. Underhill (2012) showed that J. Edgar Hoover's WAR on crime turned criminals into PUBLIC ENEMIES. This transformation undermined congressional oversight of the Federal Bureau of Investigation, allowed Hoover to militarize law enforcement, and associated any questioning of law enforcement's methodologies as sympathizing with the enemy. More troublesome for WAR metaphors is that the ENEMY is often not an external agent but, as in Gerald Ford's WAR on inflation (Stelzner, 1977), copyright holders' WAR on PIRACY (Mirghani, 2011), and other cases, the ENEMY is the public expected to support the WAR. That is, without a careful creation of an external ENEMY, the WAR becomes against the speaker's own people, encouraging suspicion of fellow citizens and internal political division rather than the unity of purpose a WAR metaphor should provide.

Moreover, WARS must end in VICTORY. This VICTORY is not always possible. Stelzner's (1977) analysis of Gerald Ford's WAR on inflation, for instance, found that, because Ford did not provide solutions with certainty and strength, the metaphor became inauthentic and the public could not understand how his proposed actions contributed to a VICTORY condition. As Ivie (2005) concludes in his discussion of George W. Bush's WAR on terror, and he places that WAR in conversation with Hoover's WAR on crime and Johnson's WAR on poverty, "a world completely free of terrorism, like a world free of crime, disease, or conflict and competition, is inconceivable" (p. 144). That is, if there is not a nation-state as an enemy that can be defeated, metaphorical WARS become endless and self-justifying. This self-justification can divert both attention and policy away from other problems and makes it impossible to end the WAR, as no nation wishes to admit that it has been DEFEATED by the ENEMY.

It is not enough, then, to invoke a metaphor. The political leader invoking the WAR metaphor must execute the metaphor fully and supply all the necessary entailments. The entailments of declaring WAR must allow policy action to occur and that policy action should be consistent with and coherent with the WAR metaphor if we are to judge the use of that metaphor to be successful.

\section{METHODS}

To perform this analysis and to render judgment on Trump's WAR, I use the five-step method first offered by Ivie (1987) and clarified by Bates (2004).

The first step is for the rhetorical critic to locate themselves into the speaker's context. In this step, the critic seeks to "create a sense of the complete experience before attending to its particulars" by consulting with sources produced alongside and with the text they seek to analyze and with relevant scholarship regarding the text or similar texts (Ivie, 1987, p. 167). The consultation with sources produced contemporaneously may include media coverage, audience reactions, texts produced to counter the text of interest, and others. Consultation with relevant scholarship can include historical accounts, theoretical analyses, and other rhetorical critiques of the same text. Generally, the closer in time the analysis is produced to the text under analysis, the more contemporaneous sources will be used, while the further removed the critic is from historical texts the more she or he will rely on previous scholarship. Because this is a rapid rhetorical analysis, it emerged within the same political context addressed by Trump and most of the familiarization with the political context came through contemporary media accounts and surrounding texts. And, significant to the understanding of the biomedical context of the speech, it is significant to note 
that this author investigates, primarily, public understanding of neglected and emergent tropical diseases and draws on that experience in this analysis.

The second step is to read the whole of the texts offered by the rhetor to the public, select a representative text and search it for metaphorical vehicles that help explain that context. Specifically, I was immersed, along with much of the US public, in Trump's speeches, press conferences, social media accounts, and other statements about SARS-CoV-2 and COVID19, along with statements from Vice-President Mike Pence, members of the US Coronavirus Task Force, state governors, and other governmental and media personalities. As representative texts, I selected Trump's Twitter feed (https://twitter.com/ realDonaldTrump) and Trump's statements during the White House daily briefings from March 13 between 00:00 a.m. and March 23 at 11:59 p.m. (Remarks, 2020a,b,c,d,e,f,g,h). I chose these texts because the President is generally a condensation point for interpreting public events, both providing a summary of the Administration's overall response and serving to direct future responses. This time period represents the Administration's first sustained response to SARS-CoV-2 through Congress's initial passage of a package of measures to respond to SARS-CoV-2. Moreover, these 10 days of Trump's tweets and statements offers a consistent preferred metaphorical vehicle preferred by the Trump Administration: that the struggle against SARS-CoV-2 is a WAR.

After identifying these texts for closer analysis, the third step is to examine the WAR vehicle and identify the entailments that emerge from the deployment of that vehicle. In this step, the critic sorts and categorizes the entailments to determine the metaphorical concepts that come together to characterize the fuller text. Specifically, the critics reads and re-reads the text. Once she or he has identified a metaphor that motivates the text, she continues re-reading the text, marking the occurrence of vehicles that further the metaphor and the immediate context in which those vehicles manifest. At the end of this markingwhether performed on paper using highlighters or in a word processing or discourse analysis program-the critic will have "an abridged version [of the text] that comprises only marked vehicles and their immediate contexts" (Ivie, 1987, p. 167). These can be arranged, in a procedure similar to Burke's (1937) cluster analysis, into groupings that indicate how the speaker has sorted the different entailments and implications of the metaphor to create a system of understanding for auditors. See Table $\mathbf{1}$ for the arrangements representative of the clustering in Trump's texts.

In the fourth step, the critic associates elements of the immediate contexts with the metaphorical concepts and entailments that respond to those contexts. This step involves a return to the text. With the list of all of the vehicles associated with the WAR metaphor, the text is searched for all occurrences of those vehicles, even those missed in the previous rounds of reading. This procedure creates an exhaustive manifest of all of the speaker's use and re-use of these vehicles. It also reveals contexts where vehicles co-occur with vehicles from other clusters and where they are isolated form other clusters, as well as revealing contexts where entailments are consistent and where they are inconsistent.
Finally, after all the concepts are associated with context and entailments, the critic analyzes the speaker's metaphor, how it shapes and limits conceptual and policy responses, and "assess both the limits and untapped potential of the metaphorical system" (Ivie, 1987, p. 168). This stage is the least structured, as it relies on the critic to focus on identifying patterns within the texts and to engage in interpretation of the text to make manifest latent meanings.

\section{ANALYSIS}

Trump's discussion of SARS-CoV-2 centers on a metaphor of WAR. In his fullest statement on how the efforts to control SARS-CoV-2, Trump explicitly compared the current effort to the Second World War. At his March 18, Trump argued:

Every generation of Americans has been called to make shared sacrifices for the good of the nation. In World War Two, young people in their teenage years volunteered to fight. They wanted to fight so badly because they love our country. Workers refused to go home and slept on factory floors to keep assembly lines running. And, you know, the numbers of ships that they built during World War Two, to this day has never-nothing like that has ever been equal. They were doing ships on a-literally on a daily basis. Nobody has ever seen anything like it. To this day, nobody has seen anything like what they were able to do during World War Two. And now it's our time. We must sacrifice together because we are all in this together and we'll come through together. It's the invisible enemy. That's always the toughest enemy: the invisible enemy. But we're going to defeat the invisible enemy. I think we're going to do it even faster than we thought. And it will be a complete victory. It'll be a total victory. (Remarks, 2020f)

Calling on the public memory of World War II and, in particular, the role of citizens on the homefront, Trump activated the WAR metaphor. Suggesting images of Victory Gardens, Rosie the Riveters, and other hallmarks of the so-called "Greatest Generation," World War II is recalled as a noble effort that united nations around the world against a seemingly invincible evil. But, unlike international efforts in World War II, Trump declared a WAR against an invisible enemy present on domestic soil. In this effort, Trump named his position; he said at a press conference on March 22, "I'm a wartime president. This is a war. This is a war. A different kind of war than we've ever had" (Remarks, 2020g).

In comparing his government's efforts to counter SARS-CoV2 to a war, the metaphor of WAR creates a series of entailments for the metaphor to be completed. Because metaphors demand cognitive and affective associations, metaphors encourage the auditor to attend not only to the definition of this strugglethis struggle is a WAR-but also to what else a WAR requires. Even though Trump acknowledged that this is "a different kind of war than we've ever had," the metaphor demands that this WAR resemble other, actual wars in which the nation has fought. In the 10 days following his declaration that this is a WAR, Trump also offered the entailed positions for the ENEMY, SOLDIERS, HOMEFRONT ACTION, and VICTORY. In doing so, Trump completed the metaphor and offered the entailments 
TABLE 1 | Metaphor clusters emergent in Donald Trump's rhetoric.

\begin{tabular}{|c|c|c|}
\hline Vehicles (source domains) & Entailments (cognitive targets) & Exemplars \\
\hline WAR & $\begin{array}{l}\text { Wars require an enemy } \\
\text { Wars require sacrifice on the homefront } \\
\text { Wars require soldiers } \\
\text { Wars require victory }\end{array}$ & $\begin{array}{l}\text { To this day, nobody has seen anything like what they were able to do during World } \\
\text { War Two. And now it's our time. We must sacrifice together because we are all in } \\
\text { this together and we'll come through together. It's the invisible enemy. That's } \\
\text { always the toughest enemy: the invisible enemy. But we're going to defeat the } \\
\text { invisible enemy. I think we're going to do it even faster than we thought. And it will } \\
\text { be a complete victory. It'll be a total victory. }\end{array}$ \\
\hline WARTIME PRESIDENT & $\begin{array}{l}\text { Wars require the president be a military, not } \\
\text { civilian, leader }\end{array}$ & $\begin{array}{l}\text { I'm a wartime president. This is a war. This is a war. A different kind of war than } \\
\text { we've ever had. }\end{array}$ \\
\hline ENEMY & $\begin{array}{l}\text { The enemy is an aggressor } \\
\text { The enemy is foreign } \\
\text { The enemy is monstrous }\end{array}$ & $\begin{array}{l}\text { It's now attacking - the enemy is attacking } 144 \text { countries at this moment. One } \\
\text { hundred and forty-four. That's unthinkable. There's never been anything like this. And } \\
\text { it's vicious. It is vicious. } \\
\text { Like our earlier, very aggressive actions with China, this measure will save } \\
\text { countless lives. } \\
\text { The onslaught of the Chinese Virus is not your fault! }\end{array}$ \\
\hline SOLDIERS & $\begin{array}{l}\text { War makes medical professionals into soldiers } \\
\text { War makes ordinary people into heroes }\end{array}$ & $\begin{array}{l}\text { We are at war with an invisible enemy, but that enemy is no match for the spirit } \\
\text { and resolve of the American people...... It cannot overcome the dedication of our } \\
\text { doctors, nurses, and scientists - and it cannot beat the LOVE, PATRIOTISM, } \\
\text { and DETERMINATION of our citizens. Strong and United, WE WILL PREVAIL. } \\
\text { This afternoon, I'll be meeting with nurses on the frontlines of the battle against the } \\
\text { virus. They are truly American heroes. } \\
\text { I want to take a moment to thank the everyday heroes who are making our vast } \\
\text { effort against the virus possible. And thank you to the ... Thanks also to the } \\
\text { hardworking men and women of Federal Express, UPS, the United States Postal } \\
\text { Service, and the truckers who are maintaining our supply chains and supply lines. }\end{array}$ \\
\hline HOMEFRONT & $\begin{array}{l}\text { The homefront involves everyone } \\
\text { The homefront requires collective action and } \\
\text { collective sacrifice } \\
\text { Weapons and materiel must be produced } \\
\text { and preserved }\end{array}$ & $\begin{array}{l}\text { We're announcing new guidelines for every American to follow over the next } 15 \\
\text { days as we combat the virus. Each and every one of us has a critical role to play in } \\
\text { stopping the spread and transmission of the virus. } \\
\text { They know they're getting through the crisis and will require an all-of-America } \\
\text { approach, and that's very important. } \\
\text { I ask all Americans to band together and support your neighbors by not hoarding } \\
\text { unnecessary amounts of food and essentials. TOGETHER we will stay STRONG } \\
\text { and overcome this challenge! }\end{array}$ \\
\hline VICTORY & $\begin{array}{l}\text { Wars must be won } \\
\text { Some deaths are inevitable } \\
\text { Economic strength means victory }\end{array}$ & $\begin{array}{l}\text { As long as I am your President, you can feel confident that you have a leader who } \\
\text { will always fight for you, and I will not stop until we win. This will be a great victory. } \\
\text { This is going to be a victory. } \\
\text { Normal life will return. And our economy will rebound very, very strongly. But, right } \\
\text { now, in the midst of this great national trial, Americans must remain united in } \\
\text { purpose and focused on victory. } \\
\text { When we win the war against the virus, we want to make sure those companies } \\
\text { are ready to charge forward - not that they've been disbanded because we were } \\
\text { pennywise and dollar foolish. } \\
\text { I think it's going to be a tremendous day when we win this war-and we will win the } \\
\text { war. We want to win the war with as few-if you look at it-just deaths as possible. } \\
\text { We want to have as few number of deaths as possible. }\end{array}$ \\
\hline
\end{tabular}

he wanted auditors to adopt. Largely, these entailments fit well with Trump's other isolationist, America First policies, and privilege economic advancement over other forms of well-being. As I will demonstrate below, the fulfillment of these entailments and Trump's specific proffers create several ethical challenges to the use of the WAR metaphor in non-combat situations in general and in Trump's war on SARS-CoV-2 in particular.

\section{THE ENEMY}

In a declaration of war, war is generally declared against a nation that the war declarer accuses of aggression or wrongdoing. In traditional declarations of WAR, there is an ENEMY. However, in SARS-CoV-2, there is not a state actor attacking the United States (or other nations). Like Johnson's declaration of a WAR on poverty or Reagan's declaration of a WAR on drugs, there is not a nation-state that can be directly blamed for SARS$\mathrm{CoV}-2$. Nor are there responsible decision-makers in that nationstate who can be blamed, as SARS-CoV-2 is a virus that lacks the sentience or will to engage in aggression against a people. Trump, in a Tweet on March 17 seemed to acknowledge that it was difficult to know who was responsible an identify this ENEMY. He wrote, at 3:31 p.m., "The world is at war with a hidden enemy. WE WILL WIN!” Although Trump explicitly states that there is an ENEMY, that ENEMY is hidden from view, requiring that this war be waged in ways that are different from wars against traditional, visible enemies.

There is no doubt that Trump frames this ENEMY as an aggressor. At his March 22 press conference, Trump reported, "It's now attacking-the enemy is attacking 144 countries at this moment. One hundred and forty-four. That's unthinkable. There's never been anything like this. And it's vicious. It is vicious" 
(Remarks, 2020g). It is, indeed, unthinkable that a single ENEMY would choose to attack more than three-quarters of the world's nation-states at the same time. By classifying the ENEMY as VICIOUS, Trump participates in a longstanding tradition of war rhetors claiming that their enemy is savage or subhuman (Ivie, 1980). The inclusion of the entailment that the enemy is SAVAGE is some way may motivate the audience into seeking the enemy's destruction, as the SAVAGE must be opposed by the civilized (Bates, 2004). However, in this statement (and in others), Trump does not name the aggressor state that is attacking, leaving a significant gap in the entailments.

This inability to name a nation-state or an evil actor would seem to vitiate the metaphor. A WAR, after all, demands that there be an ENEMY and that ENEMY be definable. This is what Ivie (2005) found troubling about Johnson's WAR on poverty, as the need for an ENEMY turned this WAR into a war on poor people, and what Mackey-Kallis and Hahn (1994) found troubling about the WAR on drugs, as drug users became the ENEMY. Trump, however, through his public statements following the declaration of WAR did create a clear association with a nation-state to offer a subject position for the ENEMY to occupy: the People's Republic of China.

At his March 18 press briefing, Trump opened his statement by saying,

I would like to begin by announcing some important developments in our war against the Chinese virus... We'll be invoking the Defense Production Act, just in case we need it. In other words, I think you all know what it is, and it can do a lot of good things if we need it. (Remarks, 2020f)

In invoking the 1950 Defense Production Act, a law passed in response to production needs during the Korean War, Trump further cements his powers a wartime president. In doing so, Trump is able to adopt an authoritarian posture and makes criticism of his action more difficult, as questioning his actions can be associated with undermining the war effort. More interesting, however, is that Trump names this is a WAR against a Chinese virus, conflating the virus as ENEMY and a national actor as ENEMY. This virus, although present around the world, is declared the property of China, assigning responsibility for it to the People's Republic of China.

This statement marks a significant shift from Trump's statement at a briefing on March 13, when he reported "several decisive new actions we're taking in our very vigilant effort to combat and ultimately defeat the coronavirus" (Remarks, 2020b). The shift from "coronavirus" to "Chinese virus" may appear textually small, but it has large implications in moving from a scientifically-supported descriptive term to an accusative term that assigns responsibility for the existence of the virus. Moreover, this is not an accidental invocation of China as the probable ENEMY. As widely reported in the media with clear photographic evidence, on March 19 Trump intentionally crossed-out "Corona" and replaced it with his handwritten "Chinese" in his prepared remarks discussing the virus (e.g., Coleman, 2020; Photo of Trump, 2020).
Trump claimed multiple times that a Chinese virus was the ENEMY, furthering this association between the state actor and the virus. Early on, on March 13 at a press conference, Trump stated that US aggression was associated with China: "Like our earlier, very aggressive actions with China, this measure will save countless lives" (Remarks, 2020b). This would become a theme for the next 10 days. For example, on March 15 at 1:02 p.m., he tweeted that it is was a "Great decision to close our China, and other, borders early. Saved many lives!" On March 16, at 6:51 p.m., Trump arrayed US National action against the Chinese, stating, "The United States will be powerfully supporting those industries, like Airlines and others, that are particularly affected by the Chinese Virus." On March 18, at 6:41 a.m., he tweeted a promise to business that "money will soon be coming to you. The onslaught of the Chinese Virus is not your fault!" In doing so, the fault lies elsewhere, and that is with China in Trump's completion of the entailment of the metaphor. Later that day, at 5:37 p.m., Trump claims, "I only signed the Defense Production Act to combat the Chinese Virus should we need to invoke it in a worst case scenario in the future." He asserted, "We're using the full power of government in response to the Chinese virus" (Remarks, 2020a), giving China clear ownership of it. Collectively, these moves position China as the ENEMY responsible for deploying this virus. This entailment renders the invisible enemy-the Coronavirus - into a visible enemy-a virus caused by Chinaand makes it possible to transfer aggression from the virus onto the Chinese state.

The fullest enactment of making China the enemy comes in a dialogue between Trump and reports at the March 18 press conference. There, this exchange took place:

Q-Okay. Why do you keep calling this the "Chinese virus"? There are reports of dozens of incidents of bias against Chinese Americans in this country. Your own aide, Secretary Azar, says he does not use this term. He says, "Ethnicity does not cause the virus." Why do you keep using this? A lot of-

THE PRESIDENT: Because it comes from China.

Q-people say it's racist.

THE PRESIDENT: It's not racist at all. No. Not at all. It comes from China. That's why. It comes from China. I want to be accurate.... No, I have a great-I have great love for all of the people from our country. But, as you know, China tried to say at one point-maybe they stopped now-that it was caused by American soldiers. That can't happen. It's not going to happen-not as long as I'm President. It comes from China. (Remarks, 2020f)

In this challenge, the reporter notes that, by associating SARSCoV-2 with China, the President has seemingly authorized attacking Chinese Americans as representatives of the enemy. The reporter also challenges the association between the virus and ethnicity. Trump, however, cements China as the source of the virus. Highlighting a clash between some Chinese government officials who subscribed to a conspiracy theory that the virus was a US-manufactured bioweapon and Trump's awareness that it was not (China Spins, 2020), Trump could have used this as an opportunity to disconnect national governments from responsibility for the virus. Instead, he turns the conspiracy 
theory around to assert that the virus comes from China and, therefore, China is responsible. In addition, aggression against Chinese and Chinese American becomes acceptable because, if China is responsible, its people (and apparently people of Chinese descent) are also responsible. Trump's declaration of love "for all of the people from our country," is reminiscent of associating persons of Japanese descent in World War II with the Empire of Japan, and implies that persons of Chinese descent are neither from the United States nor loved by Trump.

This assignment of responsibility, and the transformation of the ENEMY from the virus to a Chinese virus, helps Trump complete the WAR metaphor. Although it is rhetorically useful to have a designated ENEMY in a WAR metaphor, the utility of blaming China to Trump comes at great cost. If China is the responsible ENEMY, then it limits the ability to respond effectively to the actual threats imposed by SARS-CoV2. For example, in WAR, one does not cooperate with the ENEMY; one fights them. If China is responsible for the virus, then Trump's association undermines efforts at international cooperation between the US (and its allies) and China (and its allies) in researching and disseminating cures, treatments, or vaccines for SARS-CoV-2. Information sharing becomes less likely, as one does not share intelligence with the ENEMY. And, given that the US has outsourced a great deal of pharmaceutical and medical equipment manufacturing to China, and as one does not trade with the ENEMY during WAR, the US threatens its own supply lines in the face of SARS-CoV-2. Domestically, blaming China and Chinese people also threatens to activate parts of the treatment of the ENEMY that emerges from the association crafted with World War II. The racist incidents that have already occurred in the US, and that some claimed were authorized by Trump's rhetoric, could become the leading edge of US actions like in World War II. The US internment camps for persons of Japanese descent were justified through the association of ethnicity, nation, and responsibility; if we follow Trump's identification of the ENEMY to its logical conclusion, similar associations could lead to future oppressive treatment of persons of Chinese descent in the United States.

\section{THE SOLDIERS}

In a war, battles are fought, at the abstract level, between nations. At the practical level, a war is waged by one set of fighting men and women against another set of fighting men and women. Thus, when Trump uses a WAR metaphor, the auditor must also identify the SOLDIERS who will fight SARS-CoV-2. Trump fills in this entailment by naming medical workers, delivery persons, and restaurant and grocery store workers as the SOLDIERS.

Trump first introduces the role of the SOLDIER in a pair of tweets on March 18 at 3:14 p.m. In these tweets, Trump writes,

I want all Americans to understand: we are at war with an invisible enemy, but that enemy is no match for the spirit and resolve of the American people.......It cannot overcome the dedication of our doctors, nurses, and scientists-and it cannot beat the LOVE, PATRIOTISM, and DETERMINATION of our citizens. Strong and United, WE WILL PREVAIL! (emphases in original)
Trump offers a great deal of insight into who auditors should see as SOLDIERS. In the tweets, Trump notes that there is a WAR with and ENEMY, but that this enemy is countered by doctors, nurses, and scientists. The motivations for these nurses, doctors and, scientists are not based on health sciences, but on their LOVE, PATRIOTISM, and DETERMINATION, which makes them STRONG and UNITED, connected to the United States as WE. Collectively, these terms transform medical professionals from citizens into SOLDIERS.

Trump expands on this idea when, on March 18, immediately after sending these tweets, he invites nurses to the White House for a briefing. In a press gaggle before the meeting with nurses, Trump told the press, "this afternoon, I'll be meeting with nurses on the frontlines of the battle against the virus. They are truly American heroes. They want to get it done. They're incredible people... They're very brave. They're taking a lot of risk. incredible." (Remarks, 2020f). Trump then repeats much of this language at the briefing with nurses when he states, "today I welcome the great nurses of our country to the White House and express our gratitude for those on the frontlines in our war against the global pandemic. And it's been something, but we're winning it. We will win" (Remarks, 2020a). In both statements, Trump places nurses on the FRONTLINES in a BATTLE and in a WAR. These nurses are HEROES who are BRAVE RISK-takers who seek to WIN. These characteristics assigned to nurses are not the "tender, loving care" that has traditionally been used to define the nursing profession (Kendrick and Robinson, 2002) but are, instead, terms that are generally used to describe war fighters. This rhetorical move transforms the nurses into SOLDIERS in Trump's WAR on COVID-19. This transformation, like the transformation earlier of scientists and physicians alters the placement of these professionals in meaningful ways. They are no longer seeking to improve health and knowledge; they are now against the virus. This conversion to a combat role detracts from the civilian nature of their roles, and it undermines the customary medical neutrality given to doctors, nurses, and medics. By drafting them into his war, Trump erases meaningful distinctions between combatants and non-combatants that are necessary within the law of war.

Later, on March 22, Trump expands the ranks of these SOLDIERS. He tells the press, "as we continue to marshal every resource at America's disposal in the fight against the Chinese virus, we're profoundly grateful to our nation's state and local leaders, doctors, nurses, law enforcement, and first responders who are waging this battle on the ground" (Remarks, 2020g). This MARSHALING of resources is dependent on those who would use. Here, the nurses are joined by doctors, law enforcement, and first responders as SOLDIERS who are WAGING this BATTLE. It is also significant that these SOLDIERS are battling the "Chinese virus," reinforcing the positioning of China as the ENEMY in this WAR. In this expansion, Trump also strips police officers and first responders of their civilian status.

Additional SOLDIERS are drafted into Trump's metaphorical army the next day. At the March 23 daily press briefing, Trump stated,

I want to take a moment to thank the everyday heroes who are making our vast effort against the virus possible. And thank you 
to the healthcare workers and the first responders. These are very brave people. Thanks also to the hardworking men and women of Federal Express, UPS, the United States Postal Service, and the truckers who are maintaining our supply chains and supply lines. We thank you very much. Great job. We also want to give our regards and thanks to everyone at our grocery stores working the night shift so that shelves can be restocked, and the restaurant workers and delivery drivers keeping our families fed. (Remarks, 2020h)

Trump begins by acknowledging, again, healthcare workers and first responders, but expands his forces to include delivery workers and food and grocery workers. Healthcare workers and first responders are named BRAVE and HEROES again, but, as with a non-metaphorical FRONTLINE army, the SUPPLY LINES must be maintained to have an effective fighting force. This role in supplying the metaphorical army does not require people to be BRAVE but only HARDWORKING. This incorporation of a metaphorical quartermaster corps into Trump's army battling SARS-CoV-2 furthers the entailment of who the SOLDIERS are.

Although it is rhetorically necessary for Trump's WAR metaphor to have SOLDEIRS to fight it, the transformation of these civilian workers into SOLDIERS creates challenges to the metaphor and ethical challenges. The metaphor requires the transformation of, at least, first responders and healthcare workers from civilians into military personnel. The militarization of first responders-police, medics, and firefighters-removes them from a community-based role in which they are to protect and serve and places them in a removed role in which they are SOLDIERS first. As has been well-documented (Lieblich and Shinar, 2018; Mummolo, 2018), the militarization of police symbolically and practically can lead to the police to an antisocial orientation harmful to the communities they operate in. The militarization of other first responder categories may create similar antisocial outcomes. In addition, the transformation of healthcare workers into SOLDIERS changes the helping professions drastically. Most healthcare workers seek to do no harm and to heal the sick; making them over into warriors violates this orientation materially and symbolically. Drafting the remainder of this metaphorical army may not create the same threats to professional identity to food and grocery workers and delivery workers as the transformation of healthcare workers and first responders does; nonetheless, it disrupts the operation of the metaphor. If food and grocery workers and delivery workers are SOLDIERS, then their SUPPLY LINES should go to other soldiers, not to the civilian population. If they serve the civilian population, then transforming them into SOLDIERS is inappropriate and dissonant with the metaphor. This metaphorical incoherence makes the WAR metaphor less useful in understanding national responses to SARS-CoV-2.

\section{HOMEFRONT ACTION}

As much as turning healthcare workers, first responders, delivery workers, and food and grocery workers performing work within the United States into SOLDIERS confuses the FRONTLINE with the HOMEFRONT, Trump's invocation of the Second World
War requires that there be a HOMEFRONT distinct from the area of military operations. Trump realizes that this entailment requires him to call for US citizens to engage in acts of selfsacrifice to support efforts on the FRONTLINE. Therefore, on March 16, art 3:21 p.m., he tweeted, "This afternoon, we're announcing new guidelines for every American to follow over the next 15 days as we combat the virus. Each and every one of us has a critical role to play in stopping the spread and transmission of the virus" (Remarks, 2020d). Because all citizens have an important role, the tweet anticipates a desire to know what their CRTICIAL ROLE in this COMBAT will be.

Because Trump has invoked World War II as model for the WAR on SARS-CoV-2, it would be reasonable to expect to hear him call for efforts like victory gardens, gas and food rationing, scrap drives and salvage collection to help conserve resources for the effort or, at the least, their metaphorical counterparts. We would also expect Trump to offer meaningful roles to state and local governments as sites for organizing public responses at home so that the Commander-in-Chief can focus on the frontlines. Trump largely fails to fulfill this expectation, denying meaningful participation in the efforts against COVID-19 to most of the public. Trump also fails to activate localities and states as levels of government that can meaningfully contribute. He disconnects people, municipalities, and states from this WAR. In creating possibilities for the HOMEFRONT, Trump largely failed to offer appropriate entailments. The most direct parallel to World War II was Trump's statements addressing hoarding. In his March 16, 4:49 p.m. tweet ("I ask all Americans to band together and support your neighbors by not hoarding unnecessary amounts of food and essentials. TOGETHER we will stay STRONG and overcome this challenge!") and a brief statement at the March 24 press conference ("I signed an executive order ... to prohibit the hoarding of vital medical equipment and supplies such as hand sanitizers, face masks, and personal protective equipment" (Remarks, 2020h)], Trump offered the first CRITICAL ROLE that resembled wartime actions. For the most part, however, the actions Trump makes available to everyday people are not those of CIVILIANS on the HOMEFRONT, but are, instead, merely living ordinary life, a practice dissonant with the metaphor of WAR.

The second CRITICAL ROLE on the HOMEFRONT, if read generously by auditors, is participating in the workforce. The call for COLLECTIVE SACRIFICE is common in WAR, and Presidents can encourage particular actions. Trump chose to focus on sacrifice, not by people, but by the companies for which they work. On March 15, Trump reported on the efforts companies were willing to make:

They know they're getting through the crisis and will require an all-of-America approach, and that's very important. They're committed to remaining open during this crisis. Totally open. They have to stay open. Those stores have to stay open. They supply our country. (Remarks, 2020c)

In this circular statement, the inclusion of "all of America" denotes a collective sacrifice, but this sacrifice is operationalized as one made by retailers. Companies, however, cannot function 
without workers. This may be why, on March 17, Trumps expanded his remarks to include working people. He said,

\begin{abstract}
We're taking aggressive action now as one nation and one family so that America can rebound stronger-frankly, stronger than ever before. And we recognize that while many American workers can work from home, many others cannot. Many of our healthcare providers, first responders, and men and women in the food service and manufacturing are showing at-they're showing up and standing up to provide us with the goods and services we need. So we want people to stay home where they can, but in many cases, when you talk about food service and manufacturing, certain items in particular, they are-they're going in and they're practicing all of the safety rules and regulations that we talk about. (Remarks, 2020e)
\end{abstract}

In this statement there may be some parallels to calls in World War II to keep domestic industries operational, although those industries are expanding from the manufacture of materiel and supplies to include food service and service work from home. The call for current workers to keep working also differs from the call in World War II as, in that War new workers-primarily women and people with disabilities-entered the workforce to replace able-bodied men who were sent to military service. And, in a final note of difference, and in the further disruption of the WAR metaphor, Trump encourages as many people as possible to stay home to work rather than calling on them to adopt new, essential roles in the workforce. What remains missing, however, is how ordinary work in food service or manufacturing, or how staying home and not working in the workplace, are connected into efforts toward fighting COVID-19. The entailment is not complete and may cause confusion for the auditor.

Trump or his staff may have recognized that they were undermining the WAR metaphor. In the last item in this speech set, a press conference on March 24, Trump noted,

\begin{abstract}
All throughout the country, we're witnessing extraordinary acts of compassion, benevolence, and unity. Construction companies are donating masks by the hundreds of thousands. Manufacturing workers are transforming their assembly lines. Citizens are volunteering to deliver food and medicine to the elderly. We're truly seeing America at its best." (Remarks, 2020h)
\end{abstract}

These acts are far more in line with the WAR metaphor for action on the HOMEFRONT. The recognition that companies are providing masks to hospitals and that some manufacturers were retooling production lines reflects the actions that civilian industry can take during wartime. These are policy and practical changes that align well with the metaphor. The refocus of production on MATERIEL rather than consumer goods and directing ESSENTIAL SUPPLIES to the FRONTLINE helps sustain Trump's WAR metaphor.

Of the entailments of the WAR metaphor, Trump's interpretation of the HOMEFRONT appears to be the most consistent (following the late correction) and the most ethical. Although the distinction between FRONTLINE and the HOMEFRONT is very blurry, Trump does focus the metaphor in a way that could prove productive to encouraging industry to redirect personnel and resources to create WEAPONS and MATERIEL that will enable the SOLDIERS in the WAR on SARS-CoV-2. Moreover, through the deployment of the WAR metaphor, these become CRITICAL ROLES, not optional ones, perhaps engendering a collective commitment and COLLECTIVE SACRIFICE by the broader public. These moves may prove rhetorically useful should there be a national demand to shelter-in-place, as the notion of SACRIFICE has already been activated, and, by incorporating a demand to work from home, this sheltering may become consistent with the idea of how the public can participate on the HOMEFRONT.

\section{VICTORY}

This COLLECTIVE SACRIFICE and the actions of SOLDIERS on the FRONTLINE and citizens on the HOMEFRONT require one final step to complete the WAR metaphor; we must know when we have attained VICTORY. It might seem obvious that, in a WAR against a virus, elimination of SARS-CoV-2 would constitute VICTORY. And, indeed, on March 22, Trump promised VICTORY, stating,

\footnotetext{
For those worried and afraid, please know: As long as I am your President, you can feel confident that you have a leader who will always fight for you, and I will not stop until we win. This will be a great victory. This is going to be a victory. And it's going to be a victory that, in my opinion, will happen much sooner than originally expected. (Remarks, 2020g)
}

In providing these reassurances that as a LEADER, Trump would FIGHT until we WIN with VICTORY, Trump fulfilled the requirement that WAR end in VICTORY. In addition, Trump stated on March 24 perhaps the clearest encapsulation of this WAR. He reported,

\begin{abstract}
America continues to mobilize every segment of our society to turn the tide in the battle against the virus. I want Americans to know that we will get through this challenge. The hardship will end; it will end soon. Normal life will return. And our economy will rebound very, very strongly. But, right now, in the midst of this great national trial, Americans must remain united in purpose and focused on victory. (Remarks, 2020h)
\end{abstract}

In stating this, Trump seemed to assure the US public that, if they MOBILIZE in this BATTLE, they will attain VICTORY. This VICTORY would be accompanied by a return to pre-war conditions and normal life, and it would end soon. And, with the unity of purpose, normality would also be accompanied by economic restoration.

This turn to economic restoration, however, became the defining condition for VICTORY for Trump. After laying out the part of the Defense Production Act that he would activate on March 22, Trump turned, not to defeating the virus as the condition for victory, but the remobilization of the US economy:

This will help our economy, and you will see our economy skyrocket once this is over. I think it's going to skyrocket. It's ait's a pent-up demand. It's a built-up demand. And I guess you 
really have to say, "Who knows?" But I think it's going to be a tremendous day when we win this war-and we will win the war. We want to win the war with as few-if you look at it_just deaths as possible. We want to have as few number of deaths as possible. (Remarks, 2020g)

By the end of this statement, Trump argues that the US wants to WIN with as few deaths as possible, but the reason for fewer deaths seems not to be because he regards lives as valuable. There is an incipient tension between saving lives and saving the economy, a tension that will be resolve din favor of supporting the economy. Rather, he seems to position American lives as necessary to the main purpose of participating in economic exchange. He firms up this position at the press conference when he states:

It's-to me, it's not very complicated. We have to help the worker. We have to save the companies. Because as soon as we're finished with this war-it's not a battle; it's a war-as soon as we're finished with this war, our country is going to bounce back like you've never seen before. (Remarks, 2020g)

Here, Trump makes clear that this is not just a BATTLE, but a WAR. And, at the end of the WAR we will know that VICTORY is complete because the economy will become robust again. Issues of health and disease disappear as reasons for battling SARSCoV-2; instead, it becomes about the economy. And, lest it be possible that helping workers (as people) also helps corporations (as economic entities), Trump immediately places the interests of the human worker as in service to the companies. He says,

We want to take care of the worker, but we want to make sure that when we win the war-it's only a question of - it's "when," not "if." When we win the war against the virus, we want to make sure those companies are ready to charge forward-not that they've been disbanded because we were pennywise and dollar foolish. (Remarks, 2020g)

Yes, Trump acknowledge that the WAR against the virus will be WON, but his primary concern is that companies are ready to ADVANCE at its conclusion. The economic interests of companies become paramount in Trump's victory conditions. To declare VICTORY, then, does not require stamping out COVID-19, creating a vaccine, or any other health intervention/ VICTORY demands economic productivity.

In fact, Trump appears to believe that people will only be happy and healthy when the corporations are saved, thereby converting the purpose of this war from a WAR ON DISEASE to a WAR FOR THE ECONOMY. Trump, at his March 24 press conference confirms this shift when he says,

This [virus] is going away. We're-we're going to win the battle, but we also have-you know, you have tremendous responsibility. We have jobs, we have-people get tremendous anxiety and depression, and you have suicides over things like this when you have terrible economies. You have death. Probably and-I mean, definitely would be in far greater numbers than the numbers that we're talking about with regard to the virus. So, we have an obligation; we have a double obligation. We have a great country.
There's no country like it in the world, and there's no economy like it in the world. I mean, we had-we were-we were just blazing. (Remarks, 2020h)

In a series of moves, Trump converts the ENEMY from the SARS-CoV-2 virus to a poor economy, disrupting his own WAR metaphor. Indeed, the virus is just "going away," nearly as if on its own. The United States is not driving the virus away. The deaths are not caused by the ENEMY he has named; COVID19 no longer kills. Rather, people die of anxiety, depression, and suicide from a weak economy. Trump asserts without any foundation that more people will commit suicide in a bad economy that would die of exposure to SARS-CoV-2. Thus, rather than the defeat of the virus becoming the condition for VICTORY, VICTORY becomes a strong economy.

This change in VICTORY is, as with most other entailments offered by Trump, problematic both for the metaphor and for policy. If the reason to wage WAR against SARS-CoV-2 is for economic reasons, then Trump has mobilized the wrong SOLDIERS. He should not be relying on healthcare workers as the core of his army but should instead mobilize some other force. The COLLECTIVE ACTION that calls staying at home would need to be replaced with actions that promote greater economic engagement. The FRONTLINE and the HOMFRONT become even less distinguishable, as there is now little separation between the terrain of economic action to fight for a stronger economy and the place from which to support this fight. By turning VICTORY from defeating SARS-CoV-2 to creating economic strength, Trump's WAR metaphor becomes a confused mishmash, causing conceptual and policy disruptions that undermine effective rhetorical and political responses to the threat of SARS-CoV-2.

\section{CONCLUSION AND IMPLICATIONS}

When Donald Trump was asked directly on March 18 if he saw himself as a wartime president, he replied,

I do. I actually do. I'm looking at it that way because, you know, if-if it got out of control... And, yeah, I look at it-I view it as a, in a sense, a wartime president. I mean, that's what we're fighting. I mean, it's-it's a very tough situation. You're-you have to do things. (Remarks, 2020f)

Although Trump positioned himself as a wartime president, his use of the WAR metaphor was as incoherent as this response at the press conference was. Metaphors are not mere figures of speech; they are conceptual apparatuses that activate cognitive and policy responses to align with the chosen metaphor. When Trump names actions against SARSCoV-2 a WAR, he also activated expectations. He needed an ENEMY to fight using SOLDIERS on the FRONTLINE with the support of COLLECTIVE SACRIFICE on the HOMEFRONT to attain VICTORY. These entailments follow from his choice of metaphor.

As this rapid metaphoric analysis of entailments has demonstrated, however, Trump's choice of entailments to 
support the WAR metaphor creates an incoherent rhetoric that undermines his policy responses. By locating the ENEMY as a Chinese virus, Trump not only activates a gratuitously xenophobic rhetoric, but also risks harming international research, information, and trade relationships that may be necessary for responding to SARS-CoV-2. Naming SARS-CoV2 a Chinese virus also distracts attention from a shared ENEMY to reinforce divisions between the United States and the People's Republic of China. Trump's rhetoric creates a tension between a reality that could benefit from international collaboration and cooperation and a metaphor that emphasizes isolationism and unilateralism. And, in doing so, Trump's rhetoric undermines effective international policy responses to the threat of COVID19. By transforming healthcare workers, first responders, and delivery persons into SOLDIERS, Trump turns healing and helping and support professions into militarized ones. This transformation injures the professional ethos of these professions and moves them from serving a civilian population into being part of a larger war machine. In addition, Trump's rhetoric manifests a tension between a reality in which helpers and healers seek to use constructive and investigative skills to improve wellbeing and a metaphor that sacrifices the nature of those skills to make them into destructive weapons. The COLLECTIVE SACRIFICE, which in previous wars would call for public action, is framed largely as personal inaction; people are told to stay at home. Those who are working on the HOMEFRONT are already working, undermining the idea that WAR can call new people in to support struggles against challenging threats. This tension between a metaphor that should call for public action that requires sacrifice and a reality in which most people will stay at home and live their lives with little change limits effective public participation. Although the public could be asked to sacrifice old clothes to make masks for people, to plant victory gardens so that they need not venture to grocery stores, or to avoid non-essential travel would all be reasonable entailments of COLLECTIVE SACRIFICE on the HOMEFRONT. Yet, Trump fails to deploy his metaphors in a way that makes this request. Finally, the terms of VICTORY identified by Trump make health and disease a secondary issue; Trump's victory is about saving economies, not about saving lives. Trump not only creates a tension between saving the health of the nation and saving the economy of the nation, he alienates and violates the assumptions of his own metaphor. The VICTORY does not fit the WAR fought, the ENEMY named, or the SOLDIERS deployed. In sum, Trump uses the WAR metaphor so poorly in fleshing out its entailments that it makes his rhetoric and policy poor responses to SARS-CoV-2. These four failures-calling out the wrong enemy, deploying the wrong soldiers, asking for the wrong sacrifices, and identifying the wrong victory condition-lead to a series of tensions that make US response to SARS-CoV-2 ineffectual at best. More likely, Trump's rhetoric, and its incoherencies, are harmful to international cooperative efforts to address the virus and are likely to prolong suffering.

Although the WAR metaphor aligns well with the President of the United States' role as Commander-in-Chief of the armed forces, this is not the only symbolic position available to the President. Because Trump's use of the WAR metaphor is so poor, we should reject his use of the metaphor and refuse to accept the entailments he offers. As Lakoff (2004) states, "because language activates frames, new language is required for new frames. Thinking differently requires speaking differently" (p. xv). We should, therefore, encourage Trump to seek out alternative ways of framing the struggle against SARS-CoV-2, asking him to use different metaphors with different entailments. We could, for example, draw on the other roles a President is supposed to play in the United States. For example, in their treatment of Ronald Reagan as "faith healer" for the nation, Crable and Vibbert (1983) found that policy possibilities were expanded when the President shifted his role. Alternatively, Hart and Pauley (2005) argue that, within the framework of American civil religion, the President is called upon to provide guidance as a priest and prophet to the nation, a possibility that would allow Trump to speak to US values to legitimate non-militarized rhetorical responses to SARS-CoV-2. And, perhaps at the most general level, Stuckey (1991) notes that the President's main role is to serve as the "Interpreter in Chief" (p. 1); the President enters the homes of television viewers to translate news, events, and policies in a friendly way and builds an assurance of consensus that the government is enacting sound policies. That is, as Interpreter-inChief, rather than Commander-in-Chief, Trump could serve as a reporter or emcee, allowing actual experts on SARS-CoV-2 and public health policy to state best practices and then use the power of the Presidency to assure the public that these experts will serve the collective well. These alternative roles, and the metaphors that accompany them, may be better rhetorical resources for Trump to draw on.

We must also remember that Trump is not the only actor circulating the metaphor of this struggle as a WAR. In the larger media, and perhaps in our own discussions, we may have deployed Trump's metaphor and its entailments. We must choose not to use the WAR metaphor. In our own discussions with students, community members, journalists, and other people who ask us to discuss and evaluate Trump's rhetoric, we should also eschew the WAR metaphor, refusing to accept his framing. By deploying ourselves other metaphors that align with struggle and betterment, but that do not accept WAR as a framing, we can also contribute to alternative ways of providing a more coherent rhetorical and policy response to the threat of SARS-CoV-2.

\section{DATA AVAILABILITY STATEMENT}

Publicly available datasets were analyzed in this study. All data are housed at either Twitter (https:// twitter.com/realDonaldTrump) or the White House (https://www.whitehouse.gov/briefings-statements/).

\section{AUTHOR CONTRIBUTIONS}

The author confirms being the sole contributor of this work and has approved it for publication. 


\section{REFERENCES}

Bates, B. R. (2004). Audiences, metaphors, and the Persian Gulf War. Commun. Stud. 55, 447-463. doi: 10.1080/10510970409388631

Bennett, B., and Berenson, T. (2020, 19 March). 'Our big war.' As coronavirus spreads, Trump refashions himself as a wartime president. Time. Available online at: https://time.com/5806657/donald-trump-coronavirus-war-china/

Burke, K. (1937). Attitudes Toward History. Boston, MA: Beacon.

Butterworth, M. L. (2008). Purifying the body politic: Steroids, Rafael Palmeiro, and the rhetorical cleansing of Major League Baseball. West. J. Commun. 72, 145-161. doi: 10.1080/10570310802038713

China Spins (2020, 13 March). China Spins tale that the U.S. Army started the coronavirus epidemic. The New York Times - Breaking News, World News \& Multimedia. Available online at: https://www.nytimes.com/2020/03/13/world/ asia/coronavirus- china-conspiracy-theory.html

Coleman, J. (2020, 19 March). Photo of Trump's notes shows 'Chinese' virus written over 'coronavirus'. The Hill. Available online at: https://thehill.com/ homenews/administration/488502-photo-of-trumps-notes-shows-chinesevirus-written-over-coronavirus

Coronavirus (2020, 19 March). Coronavirus: Trump puts US on war footing to combat outbreak. BBC News. Available online at: https://www.bbc.com/news/ world-us-canada- 51955450

Crable, R. E., and Vibbert, S. L. (1983). Argumentative stance and political faith healing: "the dream will come true". Q. J. Speech 69, 290-301. doi: $10.1080 / 00335638309383656$

Edelman, M. (1971). Politics as Symbolic Action. Mass Arousal and Quiescence. Chicago, IL: Markham.

Hart, R. P., and Pauley, J. L. (2005). The Political Pulpit Revisited. West Lafayette, IN: Purdue University Press.

Hillmer, I. (2007). The way we think about diseases: "The immune defense" comparing illness to war. NAWA J. Lang. Commun. 1, 22-30.

Ivie, R. L. (1980). Images of SAVAGERY in American justifications for war. Commun. Monogr. 47, 279-294. doi: 10.1080/03637758009376037

Ivie, R. L. (1984). Speaking "common sense" about the Soviet threat: Reagan's rhetorical stance. West. J. Speech Commun. 48, 39-50. doi: $10.1080 / 10570318409374140$

Ivie, R. L. (1987). Metaphor and the rhetorical invention of Cold War "idealists." Commun. Monogr. 54, 165-182 doi: 10.1080/03637758709390224

Ivie, R. L. (2005). Democracy and America's War on Terror. Tuscaloosa, AL: University of Alabama Press.

Keen, S. (1991). Faces of the Enemy: Reflections of the Hostile Imagination. New York, NY: Harper Collins.

Kendrick, K. D., and Robinson, S. (2002). "Tender loving care" as a relational ethic in nursing practice. Nurs. Ethics 9, 291-300. doi: 10.1191/0969733002ne511oa

Knightly, P. (1975). The First Casualty. London: Deutsch Press.

Lakoff, G. (1993). "The contemporary theory of metaphor," in Metaphor and Thought,2nd Edn. ed A. Ortonoy (Cambridge: Cambridge University Press), 202-251.

Lakoff, G. (2004). Don't Think of an Elephant! Know Your Values and Frame the Debate. White River Junction, VT: Chelsea Green.

Lakoff, G., Espenson, J., and Schwartz, A. (1991). Master Metaphor List (Second Draft Copy). Available online at: http://araw.mede.uic.edu/ alansz/metaphor/ METAPHORLIST.pdf

Lakoff, G., and Johnson, M. (1980). Metaphors We Live By. Chicago, IL: University of Chicago Press.

Lieblich, E., and Shinar, A. (2018). The case against police militarization. Michigan J. Race Law 23, 105-153. doi: 10.2139/ssrn.2840715

Mackey-Kallis, S., and Hahn, D. (1994). Who's to blame for America's drug problem?: The search for scapegoats in the 'war on drugs'. Commun. Q. 42, 1-20. doi: 10.1080/01463379409369911

Mirghani, S. (2011). The war on piracy: analyzing the discursive battles of corporate and government-sponsored anti-piracy media campaigns. Crit. Stud. Media Commun. 28, 113-134. doi: 10.1080/15295036.2010.514933

Mral, B. (2006). The rhetorical state of alert before the Iraq War 2003. NORDICOM Rev. 27, 45-62. doi: 10.1515/nor-2017-0218

Mummolo, J. (2018). Militarization fails to enhance police safety or reduce crime but may harm police reputation. Proc. Natl. Acad. Sci. U.S.A. 115, 9181-9186. doi: $10.1073 /$ pnas. 1805161115

Photo of Trump (2020, March 19). Remarks shows 'corona' crossed out and replaced with 'Chinese' virus. NBC News. Available online at: https://www. nbcnews.com/politics/donald-trump/photo-trump-remarks- shows-coronacrossed-out-replaced-chinese-virus-n1164111

Remarks (2020a, 18 March). Remarks by president Trump and vice president pence in a briefing with nurses on COVID-19 response. The White House. Available online at: https://www.whitehouse.gov/briefings-statements/ remarks-president-trump-vice-president-pence-briefing-nurses-covid-19response/

Remarks (2020b, 13 March). Remarks by president Trump, vice president pence, and members of the coronavirus task force in press conference. The White House. Available online at: https://www.whitehouse.gov/briefings-statements/ remarks-president-trump-vice-president- pence-members-coronavirus-taskforce-press-conference-3/

Remarks (2020c, 15 March). Remarks by president Trump, vice president pence, and members of the coronavirus task force in press briefing. The White House. Available online at: https://www.whitehouse.gov/briefings-statements/ remarks-president-trump-vice-president-pence-members-coronavirus-taskforce-press-briefing-2/

Remarks (2020d, 16 March). Remarks by president Trump, vice president pence, and members of the coronavirus task force in press briefing. The White House. Available online at: https://www.whitehouse.gov/briefings-statements/ remarks-president-trump-vice-president-pence-members-coronavirus-taskforce-press-briefing- 3 /

Remarks (2020e, 17 March). Remarks by president Trump, vice president pence, and members of the coronavirus task force in press briefing. The White House. Available online at: https://www.whitehouse.gov/briefings-statements/ remarks-president-trump-vice-president-pence- members-coronavirus-taskforce-press-briefing- $4 /$

Remarks (2020f, 18 March). Remarks by president Trump, vice president pence, and members of the coronavirus task force in press briefing. The White House. Available online at: https://www.whitehouse.gov/briefings-statements/ remarks-president-trump-vice-president-pence-members-coronavirus-taskforce-press-briefing-5/

Remarks (2020g, 22 March). Remarks by president Trump, vice president pence, and members of the coronavirus task force in press briefing. The White House. Available online at: https://www.whitehouse.gov/briefings-statements/ remarks-president-trump-vice-president- pence-members-coronavirus-taskforce-press-briefing- 8

Remarks (2020h, March 23). Remarks by president Trump, vice president pence, and members of the coronavirus task force in press briefing. The White House. Available online at: https://www.whitehouse.gov/briefings-statements/ remarks-president-trump-vice-president-pence-members-coronavirus-taskforce-press-conference-3/

Smith, D. (2020, 22 March). Trump talks himself up as 'wartime president' to lead America through a crisis. The Guardian. Available online at: https:// www.theguardian.com/us-news/2020/mar/22/trump-coronavirus-electionnovember- 2020

Stelzner, H. G. (1977). Ford's war on inflation: a metaphor that did not cross. Commun. Monogr. 44, 284-297. doi: 10.1080/036377577093 90140

Steuter, E., and Wills, D. (2008). At War With Metaphor: Media Propaganda and Racism in the War on Terror. Lanham, MD: Lexington Books.

Stuckey, M. E. (1991). The President as Interpreter-In-Chief. Chatham, NJ: Chatham House.

Underhill, S. (2012). J. Edgar Hoover's domestic propaganda: Narrating the spectacle of the Karpis arrest. West. J. Commun. 76, 438-457. doi: 10.1080/10570314.2012.686649

Zhang, C., and Bates, B. R. (2017). VICTORY and PEACE: the use of metaphors in Chinese president Xi Jinping's V-Day Speech. China Media Res. 13, 37-45.

Conflict of Interest: The author declares that the research was conducted in the absence of any commercial or financial relationships that could be construed as a potential conflict of interest.

Copyright $\odot 2020$ Bates. This is an open-access article distributed under the terms of the Creative Commons Attribution License (CC BY). The use, distribution or reproduction in other forums is permitted, provided the original author(s) and the copyright owner(s) are credited and that the original publication in this journal is cited, in accordance with accepted academic practice. No use, distribution or reproduction is permitted which does not comply with these terms. 